\title{
PENGARUH MANAJEMEN PENGELOLAAN BADAN USAHA MILIK DESA TERHADAP PENINGKATAN PARTISIPASI MASYARAKAT DI DESA BILA RIASE KECAMATAN PITU RIASE KEBUPATEN SIDENRENG RAPPANG
}

\author{
${ }^{1)}$ Nur Alizah, ${ }^{2}$ Monalisa Ibrahim, ${ }^{3)}$ Andi Astinah Adnan \\ Fakultas IImu Sosial dan IImu Politik, Universitas Muhammadiyah Sidenreng Rappang \\ Nuralizahp431620351a@gmail.com \\ monalisa2231@yahoo.com \\ andi.astinah.adnan@gmail.com
}

\begin{abstract}
Abstrak
Penelitian ini bertujuan untuk mengetahui Pengaruh manajemen pengelolaan Badan Usaha Milik Desa terhadap Peningkatan Partisipasi masyarakat di Desa Bila Riase Kecamatan Pitu Riase Kabupaten Sidenreng Rappang. Populasi dalam penelitian ini adalah 83 tokoh masyarakat di Desa Bila Riase yang dimana pengambilan Sampel yang digunakan yaitu Probability Sampling, dengan teknik purposive sampling dengan menggunakan Rumus Slovin dengan jumlah Sampel 45 tokoh masyarakat, penelitian ini menggunakan Metode Deksriptif Kuantitatif. Teknik Pengumpulan data yang digunakan melalui Observasi, Kuesioner(Angket), Wawancara, Studi Pustaka. Teknik Analisis data yang digunakan adalah Statistik Deksriptif, uji Kualitas Data, Uji Asumsi Klasik dengan menggunakan SPSS 16.0 dan Skala Likert. Hasil Penelitian ini Menunjukkan bahwa Pengaruh manajemen pengelolaan BUMDes dengan nilai 62,12 \% dikategorikan "berpengaruh". Adapun faktor-faktor yang mempengaruhi manajemen pengelolaan BUMDes yaitu Partisipasi ( $67 \%$ )Sumber daya manusia ( $64 \%$ ) dengan hasil akumulasi sebesar 65,5\% atau dikategorikan "berpengaruh". Sehingga Manajemen Pengelolan Badan Usaha Milik Desa terhadap Peningkatan Partisipasi Masyarakat di Desa Bila Riase Kecamatan Pitu Riase Kabupaten Sidenreng Rappang dengan hasil 50,02\% dikategorikan kurang berpengaruh.
\end{abstract}

Kata kunci: Manajemen dan Partisipasi masyarakat

\begin{abstract}
This research aims to determine the management of the village owned enterprises to increase community participation in the village if Riase District Pitu Riase District Sidenreng Rappang. The population in this study is 83 community figures in the village Bila Riase where the sampling used is Probability Sampling, with purposive sampling technique using formula Slovin with the number of samples 45 community leaders, This research uses quantitative dexsriptif methods. Data collection techniques used through observation, questionnaire (Angket), interview, literature study. The data analysis techniques used are the DEKSRIPTIF statistics, the Data quality test, the classic assumption test using SPSS 16.0 and the Likert scale. The results of the study showed that the influence management of BUMDes with a value of $62.12 \%$ is categorized as "influential". The factors that affect the management of BUMDes are participation (67\%) human resources (64\%) with accumulated results of $65.5 \%$ or categorized as "influential". To improve the management of village owned enterprises to increase community participation in the village if Riase District Pitu Riase District Sidenreng Rappang with results 50.02\% categorized less influential.
\end{abstract}

Keywords: management and community participation

JIA $\mid$ Volume 9 | Nomor 1 | Edisi April 2021 


\section{A. PENDAHULUAN}

Indonesia dikenal sebagai negara kepulauan yang didalamnya terdapat banyak pulau. Pada setiap pulau selain perkotaan juga memiliki desa yang beragam. Menurut Undang-Undang No. 06 tahun 2014 pasal 1 ayat 1 menyebutkan bahwa desa dihormati oleh pemerintah Negara Kesatuan Republik Indonesia. Badan Pusat Statistik (BPS) tahun 2016 mencatat bahwa desa pada tahun 2018 yang dihitung berdasarkan tepi laut dan bukan tepi laut berjumlah 83.901 desa. (Statistik, 2018). Jumlah desa yang terlalu banyak ini menyebabkan masalah utama di Indonesia yaitu sulitnya dalam melakukan pemerataan pembangunan yang sesuai dengan porsinya. $\mathrm{Hal}$ ini tentu menyebabkan kesejahteraan diberbagai desa pun sulit dirasakan serta masih terdapat ketimpangan sosial.

Pembangunan adalah salah satu yang dilakukan guna meningkatkan kesejahteraan seluruh kehidupan masyarakat, bangsa dan negara untuk mewujudkan salah satu yang termuat dalam UUD 1945 yang menjadi tujuan nasional. Dalam mewujudkan pembangunan nasional, desa mempunyai peranan juga karena penduduk indonesia cenderung berdomisili di daerah pedesaan yang memiliki manfaat yang lebih guna pembangunan negara dikarenakan permasalahan masyarakat banyak berdasar pada masyarakat desa dan desa merupakan tempat untuk merealisasikan tujuan negara. Sarana pembangunan dalam mewujudkan pedesaan merupakan desa dan melakukan berbagai solusi untuk mengurangi kesenjangan dikarenakan dari berbagai aspek desa masih terbelakang diantara dengan kota. Dilihat dari fasilitas, kesejahteraan, ekonomi, pendidikan dan lainnya.

Salah satu cara guna mendorong pembangunan di tingkat desa yaitu pemerintah desa diberikan kewenangan oleh pemerintah pusat mengelola dengan mandiri lingkup desa melalui lembaga-lembaga ekonomi di tingkat desa. Lembaga-lembaga tersebut salah satunya yaitu Badan Usaha Milik Desa (Budiono, 2015). Fungsi dan tujuan BUMDes bisa tercapai jika BUMDes dikelolah secara terarah dan profesional. BUMDes menjadi solusi dengan permasalahan yang ada di Desa. BUMDes diharapkan dapat mendorong dan menggerakkan perekonomian desa (Al-
Khaddash, 2013) . Keberadaan BUMDes bisa digunakan dan membantu pemerintah ketika mengelola potensi desa yang kreatif serta inovatif, sehingga bisa menjadi lapangan kerja baru agar dapat mengurangi pengangguran (Agunggunanto, 2016). (Nasution, 2009) Prasyarat utama keberhasilan program pembangunan di pedesaan yaitu dengan melibatkan partisipasi masyarakat. Partisipasi adalah keterlibatan atau keikutsertaan dalam hal ini jika dikaitkan dengan BUMDes artinya partisipasi masyarakat dalam pembentukan hingga pelaksanaan BUMDes. Partisipasi masyarakat memiliki pengaruh yang besar terhadap keberlanjutan BUMDes. Partisipasi masyarakat ini menunjukkan dukungan masyarakat dalam menciptakan pembangunan bukan hanya mendukung pembangunan. (Kasila, 2018) Pendirian BUM Desa bertujuan: (Menteri desa, pembangunan daerah tertinggal, 2015):

1. meningkatkan perekonomian Desa;

2. mengoptimalkan aset Desa agar bermanfaat untuk kesejahteraan Desa;

3. meningkatkan usaha masyarakat dalam pengelolaan potensi ekonomi Desa;

4. mengembangkan rencana kerja sama usaha antar desa dan/atau dengan pihak ketiga;

5. menciptakan peluang dan jaringan pasar yang mendukung kebutuhan layanan umum warga;

6. membuka lapangan kerja

7. meningkatkan kesejahteraan masyarakat melalui perbaikan pelayanan umum, pertumbuhan dan pemerataan ekonomi Desa; dan

8. meningkatkan pendapatan masyarakat Desa dan Pendapatan Asli Desa.

Pemerintah Desa menginginkan dengan pembentukan dan pengelolaan BUMDes dapat meningkatkan kesejahteraan masyarakat, pengembangan potensi desa dan kemandirian perekonomian desa dengan kegiatan dan usaha yang telah di kelola oleh BUMDes dengan memberdayakan masyarakat. Dalam penelitian yang dilakukan oleh Morni Kasila dan Lala M Kalopaking dalam judul partisipasi pemuda desa dalam pengembangan usaha BUMDes Tirta Mandiri dihasilkan beberapa faktor yang mempengaruhi tingkat partisipasi pemuda, faktor yang memiliki hubungan kuat dengan tingkat partisipasi pemuda dalam BUMDes yaitu tingkat komunikasi. Dimana jika 
komunikasi juga dilakukan dengan baik antara para pengelolah tentunya bisa mengembangkan keikutsertaan masyarakat dalam proses kegiatan BUMDes. Salah satu yang mempengaruhi peningkatan partisipasi masyarakat adalah manajemen pengelolaan BUMDes yang saling berkomunikasi dan bekerja sama dalam proses kegiatan BUMDes.

Partisipasi masyarakat dalam kegiatan pemberdayaan masyarakat kurang serta dalam usaha yang telah di kelola oleh BUMDes. Telah didirikan BUMDes di desa Bila Riase dengan nama Mario Marennu sebagai induk dari BUMDes tersebut, kolam pirsa dan Kuliner Pirsa. Pemerintah desa dan para pengelolah mendirikan BUMDes namun kenyataan hanya beberapa yang digunakan masyarakat. Desa Bila Riase ini terdapat salah satu objek wisata yang terkenal di Kapubaten Sidrap, dimana ketika masyarakat memanfaatkannya dengan menjajahkan usaha dijalan menuju ke tempat itu akan meningkatkan penghasilan masyarakat dan pendapatan desa namun dalam kenyataannya tidak ada masyarakat yang menjajahkan hasil potensi desa seperti yang ada di jalan menuju objek wisata ammani dan Wakka yang ada di Kabupaten Pinrang sehingga kurang dalam pengembangan usaha desa dan pengembangan BUMDes di Desa Bila Riase tidak berjalan dengan optimal sehingga penulis ingin meneliti dengan judul Manajemen Pengelolaan Badan Usaha Milik Desa (BUMDes) terhadap Peningkatan Partisipasi Masyarakat Di Desa Bila Riase Kecamatan Pitu Riase Kabupaten Sidenreng Rappang dengan tujuan untuk mengetahui Bagaimana pengaruh Manajemen Pengelolaan Badan Usaha Milik Desa (BUMDes) terhadap peningkatan partisipasi masyarakat Di Desa Bila Riase Kecamatan Pitu Riase Kabupaten Sidenreng Rappang dan Faktor-faktor apa yang mempengaruhi Manajemen Pengelolaan Badan Usaha Milik Desa (BUMDes) terhadap peningkatan partisipasi masyarakat Di Desa Bila Riase Kecamatan Pitu Riase Kabupaten Sidenreng Rappang.

Manajemen menurut (Azwar, 2014) merupakan seni dan ilmu guna melakukan suatau Tindakan untuk memperoleh tujuan. Manajemen merupakan ilmu akuntasi pengetahuan dengan kesatuan dan di sistematiskan secara terorganisasi. Berdasarkan pendapat para ahli dapat di simpulkan bahwa manajemen adalah suatu ilmu dan seni yang dibutuhkan dalam proses kegiatan pencapaian tujuan dengan menggunakan kegiatan orang lain. Menurut H.Malayu SP.Hasibuan (2009:1) manajemen hanya merupakan alat-alat untuk mencapai tujuan yang diinginkan. Manajemen yang baik akan memudahkan mewujudkan tujuan perusahaan, karyawan dan masyarakat. Dengan manajemen, daya guna dan hasil guna unsur-unsur manajemen akan dapat di tingkatkan. (Koso, Ogotan, \& Mambo, n.d.).

Bittle \& Bittle dalam (Badrudin, 2013) bahwa alam tataran praktis pengertian manajemen dibagi ke dalam beberapa definisi, antara lain bahwa manajemen menentukan kerja tim, delegasi dan hasil. Manajemen mengakui presensi intuitif, keterampilan subjektif dalam proses manajemen dan pertumbuhan pentingnya pengetahuan yang teruji sebagai satu petunjuk untuk keputusan dan tindakan manajerial. Di sisi lain, manajemen didefinisikan sebagai suatu badan pengetahuan yang dapat diajarkan, diperlukan untuk pelajaran sekolah, lembaga, dan institusi-institusi. Manajemen adalah apa yang manjer kerjakan dalam pelaksanaan pernana mereka sebagai manajer.

(Azwar, 2014) memberi batasan pengelolaan sebagai seni dan ilmu dalam perencanaan, pengorganisasian, pengarahan, pemotivasian dan pengendalian terhadap orang serta mekanisme kerja untuk mencapai tujuan, adapun pengertian dari batasan pengelolaan tersebut sebagai berikut:

1. Perencanaan yaitu suatu proses dan rangkaian kegiatan untuk menetapkan tujuan terlebih dahulu pada suatu jangka waktu/periode tertentu serta tahapan/langkah-langkah yang harus ditempuh untuk mencapai tujuan tersebut.

2. Pengorganisasian yaitu suatu proses dan rangkaian kegiatan dalam pembagian kerja yang direncanaan untuk diselesaikan oleh anggota kelompok pekerjaan, penentuan hubungan pekerjaan yang baik diantara mereka, serta pemberian lingkungan dan fasilitas pekerjaan yang kondusif.

3. Pengarahan yaitu suatu rangkaian kegiatan untuk memberikan petunjuk atau intruksi dari seorang atasan kepada bawahan atau kepada orang yang 
diorganisasikan dalam kelompok formal dan untuk pencapaian tujuan bersama.

4. Pemotivasian yaitu suatu proses dan rangkaian kegiatan yang dilakukan oleh seorang atasan dalam memberikan inspirasi, semangat, dan kegairahan kerja serta mendorong kepada bawahan untuk dapat melakukan suatu kegiatan yang semestinya.

5. Pengendalian/ pengawasan yaitu suatu proses dan rangkaian kegiatan untuk mengusahakan agar suatu pekerjaan dapat dilaksanakan sesuai dengan rencana yang telah ditetapkan dan tahapan yang harus dilalui. Dengan demikian, apabila ada kegiatan yang tidak sesuai dengan rencana dari tahapan tersebut, diadakan suatu tindakan perbaikan.

faktor -faktor yang mempengaruhi Manajemen Badan Usaha Milik Desa. (Asvi, 2017) adapun faktor -faktor nya adalah sebagai berikut

1. Partisipasi Masyarakat. Didalam melaksakanan suatu program atau pun suatu badan usaha sangat dibutuhkan pasrtisipasi masyarakat didalam nya agar semua program yang telah di rencakan oleh suatu organisasi bisa berjalan sebagaimana mestinya, selain partisipsi kondisi masyarakat juga sangat berpengaruh didalam keberhasilan program yang telah di rencanakan.

2. Sumber Daya Manusia Sumber daya manusia merupakan seluruh potensi diri atau kemampuan yang miliki oleh manusia serta karakteristik, sosial, ekonomi yang dapat dimanfaatkan untuk keperluan pembangunan dengan segala petensi meliputi kualitas dan kuantitas. Sumber daya manusia merupakan faktor-faktor yang sangat penting dalam pelaksanaan suatu kegiatan. Meski perintah -perintah pelaksanaan kegiatan telah diteruskan dengan cermat, jelas, konsisten namun jika dalam prosesnya terjadi kekurangan sumber daya manusia yang diperlukan, maka pelaksanaan program tersebut akan kurang efektif.

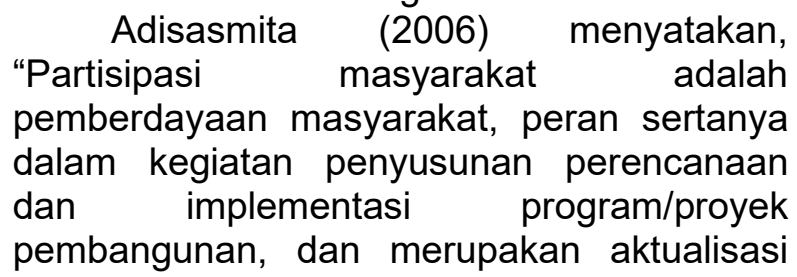

dan kesediaan dan kemauan masyarakat untuk berkorban dan berkontribusi terdahap implementasi program pembangunan". Menurut Sastropoetro dalam Samad ( 2017 : 284 ) Beberapa bentuk partisipasi meliputi :

1. Partisipasi dalam bentuk tenaga adalah partisipasi yang diberikan dalam bentuk tenaga untuk pelaksanaan usaha-usaha yang dapat menunjang keberhasilan suatu program.

2. Partisipasi dalam bentuk dana adalah partisipasi dalam bentuk menyumbang harta benda, biasanya berupa alat-alat kerja atau perkakas.

3. Partisipasi dalam bentuk informasi. Partisipasi pemberian informasi merupakan transisi antara tidak ada partisipasi dengan penghargaan. Pemberian informasi mengenai hak-hak, tanggung jawab, dan pilihan-pilihan masyarakat adalah langkah pertama menuju partisipasi masyarakat.

\section{B. METODE PENELITIAN}

Penelitian yang digunakan adalah Kuantitatif. Yakni pencarian data/informasi dari realitas permasalahan yang ada dengan mengacu pada pembuktian konsep atau teori yang digunakan. Adapun tipe penelitian kuantitatif yang digunakan yaitu deskriptif kuantitatif. Sedangkan jenis data dalam penelitian ini adalah gabungan antara data kuantitatif dengan data kualitatif. Populasi dalam penelitian ini adalah tokoh masyarakat di Desa Bila Riase Kecamatan Pitu Riase Kabupaten Sidenreng Rappang dari empat Dusun yang berjumlah 83 orang, sedangkan sampel dalam penelitian ini menggunakan rumus Slovin sebanyak 45 tokoh masyarakat. Teknik pengumpulan data yang digunakan yaitu Observasi, Kuesioner, Interview, dan Studi Pustaka sedangkan teknik analisis data yang digunakan melalui model regresi dan pengajuan hipotesis dengan bantuan SPPS.

\section{HASIL DAN PEMBAHASAN}

Manajemen pengelolaan terdapat $62,12 \%$ dari $100 \%$ yang diharapkan maka dari jumlah 62,12\% memiliki kategori "Baik". Sehingga dapat disimpulkan bahwa yang paling dalam indikator manajemen pengelolaan yaitu perencanaan $37.88 \%$ sehingga perlu untuk ditingkatkan kedepannya. Rekapitulasi Indikator partisipasi masyarakat terdapat $62,3 \%$ dari $100 \%$ yang diharapkan maka dari jumlah 
62,3\% memiliki kategori "Baik". Sehingga dapat disimpulkan bahwa yang paling dalam indikator partisipasi masyarakat yaitu partisipasi dalam bentuk tenaga $37,7 \%$ sehingga perlu untuk ditingkatkan kedepannya. Paling penting dalam setiap partisipasi masyarakat adalah bagaimana mereka berpartisipasi atau turut serta secara langsung dalam setiap kegiatan yang dilakukan karena dalam suatu kegiatan dapat dikatakan berhasil jika masyarakat tertarik dan ikut serta dalam kegiatan tersebut. Dengan banyaknya masyarakat yang ikut berpartisipasi dapat dikatakan bahwa manajemen pengelolaan dalam kegiatan tersebut berhasil dikarenakan dapat menarik minat masyarakat. Karena masyarakat dikalangan sekarangan ini mereka sibuk dengan pekerjaannya masing-masing sehingga kurang berpartisipasi ketika ada kegiatan yang dilakukan baik dipemerintah desa maupun di Badan Usaha Milik Desa tersebut. Rekapitulasi faktor-faktor yang mempengaruhi manajemen terdapat $65,5 \%$ dari $100 \%$ yang diharapkan maka dari jumlah $65,5 \%$ memiliki kategori " baik". Sehingga dapat disimpulkan bahwa yang paling kurang dalam faktor-faktor yang mempengaruhi manajemen pengelolaan yaitu sumber daya manusia sehingga perlu untuk ditingkatkan kedepannya. mengetahui jumlah dari kedua variabel yaitu maka dapat dilihat dari Rumus dibawah ini dengan menggunakan Rumus Hasil Ideal sebagai berikut :

$$
\begin{gathered}
=\frac{700+430}{5 \times 10 \times 45} \times 100 \\
=\frac{1130}{5 \times 10 \times 45}=\frac{1130}{2250}=0.50 \times 100 \%=50 \%
\end{gathered}
$$
Jika dilihat dari Rumus diatas maka terdapat $50 \%$ kurang dari $100 \%$ dimana $50 \%$ merupakan Kategori "Kurang Berpengaruh. Partisipasi masyarakat dalam manajemen pengelolaan BUMDesa tentunya sangat berpengaruh. Dikarenakan masyarakat sebagai ujung tombak suatu keberhasilan kegiatan dan merupakan tujuan dari kegiatan yang dilakukan oleh pengelolah BUMDes. Dimana pengelolaan BUMDes dapat dikatakan berhasil ketika dapat mengikutsertakan masyarakat dalam setiap kegiatannya dan masyarakat tertarik dengan apa saja yang dilakukan oleh para pengelolah BUMDes. Dimana dilihat dari tujuan pendirian BUMDes itu sendiri untuk meningkatkan kesejahteraan masyarakat dan peningkatan potensi desa tentu
p-ISSN 2302-0970

e-ISSN 2723-0201

membutuhkan partisipasi masyarakat. Coefficients diperoleh $\mathrm{t}$ hitung $=9.436$ prosedur mencari statistik dengan kriteria

1. Tingkat signifikan $(a=0,05)$ untuk uji dua pihak

2. Df atau $\mathrm{dk}$ (derajat kebebasan) $=$ jumlah data -2 atau $43-2=41$

3. Sehingga didapat $t$ tabel $=1.683$

Ternyata nilai $t$ hitung $\geq t$ tabel, atau $9.436 \geq$ 1683 maka Ho ditolak dan Ha diterima, artinya signifikan. Jadi, manajemen pengelolaan BUMDes berpengaruh/signifikan terhadap peningkatan partisipasi masyarakat di Desa Bila Riase Kecamatan Pitu Riase Kabupaten Sidenreng Rappang. Manajemen pengelolaan BUMDes dapat dikatakan mempengaruhi ketika dapat melibatkan dan meningkatkan partisipasi masyarakat dalam setiap kegiatannya. Dimana manajemen pengelolaan berfungsi sebagai:

1. Perencanaan merupakan proses kegiatan untuk menetapkan tujuan terlebih dahulu. Dengan perencanaan yang matang dapat memudahkan dalam pencapaian tujuan yang ditetapkan di BUMDes.

2. Pengorganisasian merupakan pembagian kerja yang direncanakan untuk menjalankan tugas dan fungsi masingmasing. Dengan pembagian kerja yang jelas seperti ketua, sekertaris, bendahara dan bagian-bagian lainnya tentu dapat memudahkan dalam melaksanakan tugasnya karena telah dibagi sesuai tugas dan fungsinya tanpa membebankan pekerjaan yang banyak kepada para pengelolah BUMDes.

3. Pengarahan merupakan rangkaian pemberian petunjuk yang dilakukan baik dari pemerintah dan pengelolah BUMDes dengan adanya pengarahan ini dapat memudahkan dalam proses kegiatan BUMDes sehingga kegiatan dapat berjalan sesuai dengan yang telah direncakan.

4. Pemotivasian merupakan proses dan rangkaian kegiatan yang dilakukan dalam memberi inspirasi, semangat dan kegairahan kerja untuk mendorong para pengelolah untuk melakukan suatu kegiatan yang semestinya. Dengan adanya pemberian motivasi kepada pengelolah BUMDes dapat memberikan motivasi dan semangat serta dorongan untuk melakukan inovasi dan menggali ide-ide yang baru lagi untuk pengembangan BUMDes dan lebih giat 
lagi dalam melakukan tugasnya. Dengan ide-ide yang baru diharapkan dapat menarik minat masyarakat untuk berpartisipasi.

5. Pengendalian merupakan suatu proses dan rangkaian kegiatan untuk mengusahakan agar suatu pekerjaan dapat dilaksanakan sesuai dengan rencana yang telah ditetapkan. Dengan pengendalian melalui pengawasan di pengelolah BUMDes yang sudah baik perlu ditingkatkan untuk melihat sejauh mana tujuan yang telah dicapai dan melihat setiap kegiatan yang dilakukan sesuai dengan apa yang telah direncanakan.

Selain itu, untuk memudahkan manajemen pengelolaan BUMDes tentunya ada faktor-faktor yang mempengaruhinya.

1. Partisipasi masyarakat merupakan pemberdayaan masyarakat, peran sertanya dalam kegiatan penyusunan perencanaan dan implementasi prigram/proyek pembangunan, dan merupakan aktualisasi dan kesedian dan kemauan masyarakat untuk berkorban dan berkontribusi terhadap implementasi program. Didalam melaksanakan suatu program ataupun suatu badan usaha sangat dibutuhkan partisipasi masyarakat didalamnnya agar semua program yang telah direncanakan oleh suatu organisasi bisa berjalan sebagaimana semestinya dan Dengan adanya partisipasi masyarakat manajemen pengelolaan BUMDes dapat dikatakan berhasil dikarenakan tujuan pendirian BUMDes ini diperuntukkan untuk masyarakat.

2. Sumber daya manusia merupakan seluruh potensi diri atau kemampuan yang dimiliki oleh manusia serta karakteristik,sosial, ekonomi yang dapat dimanfaatkan untuk keperluan pengelolaan dengan segala potensi melalui kualitas dan kuantitas. Dimana sumber daya manusia faktor penting dalam pelaksanaan suatu kegiatan. Dengan adanya kemampuan yang dimiliki dapat memudahkan untuk pengelolaan BUMDes dan menjalankan tugasnya dengan fungsi sesuai dengan kemampuannya. Dengan kurangnya sumber daya manusia yang dimiliki maka pelaksanaan kegiatan BUMDes menjadi kurang efektif.

Manajemen pengelolaan yang baik serta partisipasi masyarakat ada dan kemampuan dari sumber daya manusia dari pengelolah tentunya dapat meningkatkan partisipasi masyarakat tentunya tidak hanya terlibat lansung dalam setiap kegiatan tapi ikut dalam pengembangan BUMDes serta pencapaian tujuan BUMDes. Partisipasi dapat dilihat dari:

1. Partisipasi dalam bentuk tenaga adalah partisipasi yang diberikan dalam bentuk tenaga untuk pelaksanaan usaha-usaha yang dapat menunjang keberhasikan suatu kegiatan. Masyarakat berpartisipasi dalam bentuk tenaga dalam kegiatan dan usaha yang dilakukan oleh BUMDes agar tercapai tujuan pendirian BUMDes yang mana diperuntukkan untuk masyarakat itu sendiri.

2. Partisipasi dalam bentuk dana adalah partisipasi dalam bentuk menyumbangkan harta benda, biasanya berupa alat-alat kerja atau perkakas. Dengan adanya partisipasi masyarakat dalam bentuk dana, harta atau benda tentunya dapat dimudahkan dalam setiap kegiatan BUMDes.

3. Partisipasi dalam bentuk informasi adalah pemberian informasi mengenai hak-hak, tanggung jawab dan pilihan-pilihan masyarakat. Dengan masyarakat menyampaian apa saja yang dibutuhkan tentunya dapat memudahkan pengelolaan dan pengembangan BUMDes yang ditujuannya untuk kesejahteraan masyarakat.

\section{KESIMPULAN}

Berdasarkan hasil penelitian yang telah diuraikan pada bab sebelumnya. Maka dapat disimpulkan bahwa:

1. Pengaruh Manajemen pengelolaan BUMDes terhadap peningkatan partisipasi masyarakat di Desa Bila Riase Kecamatan Pitu Riase Kabupaten Sidenreng Rappang dikategorikan kurang berpengaruh dengan nilai rata-rata $50 \%$. Indikator manajemen pengelolaan yang memiliki persentase paling tinggi yaitu pengorganisasian 65, $8 \%$ sedangkan persentase yang paling rendah yaitu pengarahan $57,2 \% /$ Indikator Partisipasi masyarakat yang memiliki persentase paling tinggi yaitu partisipasi masyarakat dalam bentuk tenaga $67 \%$ dan memiliki persentase yang sama yaitu partisipasi dalam bentuk dana dan informasi dengan masing-masing $60 \%$. 
2. Faktor yang mempengaruhi manajemen pengelolaan BUMDes yang memiliki persentase tinggi yaitu partisipasi masyarakat $67 \%$ sedangkan persentase paling rendah yaitu sumber daya manusia $64 \%$.

\section{E. REFERENCE}

Agunggunanto, E. Y. (2016). Pengembangan Desa Mandiri Melalui Pengelolaan Badan Usaha Milik Desa. Jurnal Dinamika Ekonomi dan Bisnis, Vol 3, No. 1.

Al-Khaddash, H. N. (2013). Factors Affecting the Quality Of Auditing. Internasional Journal Of Bussiness and Social Sciens.

Azwar, I. R. (2014). Beban Kerja, Implikasinya Terhadap Motivasi Kerja dengan Kemampuan Kerja Sebagai Variabel Intervening pada Karyawan Bank UMKM. Jurnal Keuangan dan Perbankan, Vol 19, No.2.

Budiono, P. S. (2015). Konsep Dasar keperawatan. Jakarta: Bumi Medika.

Jamaluddin Ahmad, A. A. (2019). Model Policy Governance of Public
Transportation in Sidenreng Rappang Regency. Advances in Social Science, Education and Humanities Research, volume 410, 193-195.

Kasila, M. d. (2018). Partisipasi Pemuda Desa dalam Perkembangan Usaha BUMDes (Studi Desa Ponggok Kecamatan Polanharjo Kabupaten Klaten Jawa Tengah. Jurnal Sains Komunikasi dan Pengembangan Masyarakat, Vol 2, No. 1.

Nasution. (2009). Metode Research (Penelitian IImiah). Jakarta: Bumi Aksara.

Siti Hardianti Arkian, S. A. (2020). ANALISIS PERANAN PEMERINTAH DAERAH TERHADAP PEMBERDAYAAN MASYARAKAT KABUPATEN SIDENRENG RAPPANG (Studi Kasus Pengentasan Anak Putus Sekolah di Kecamatan Maritengngae) . JIA Jurnal IImiah Administrasi, 1-9. 